\title{
Phylogeographical convergence between Astyanax cavefish and mysid shrimps in the Sierra de El Abra, Mexico
}

\author{
Joseph Kopp', Shristhi Avasthi', Luis Espinasa' \\ I School of Science, Marist College, 3399 North Rd, Poughkeepsie, New York 12601, USA \\ Corresponding author: Luis Espinasa (luis.espinasa@marist.edu)
}

Academic editor: O. Moldovan | Received 31 May 2018 | Accepted 25 July 2018 | Published 14 August 2018

http://zoobank.org/84D5AECA-OF2A-4155-9000-C8F5817E7C7D

Citation: Kopp J, Avasthi S, Espinasa L (2018) Phylogeographical convergence between Astyanax cavefish and mysid shrimps in the Sierra de El Abra, Mexico. Subterranean Biology 26: 75-84. https://doi.org/10.3897/subtbiol.26.27097

\begin{abstract}
The Sierra de El Abra is a long $(120 \mathrm{~km})$ and narrow $(10 \mathrm{~km})$ karstic area in northeastern Mexico. Some studies have suggested independent evolutionary histories for the multiple populations of blind cavefish Astyanax mexicanus that inhabit this mountain range, despite the hydrological connections that may exist across the Sierra. Barriers between caves could have prevented stygobitic populations to migrate across caves, creating evolutionary significant units localized in discrete biogeographical areas of the Sierra de El Abra. The goal of the present study was to evaluate if there is a correspondence in phylogeographical patterns between Astyanax cavefish and the stygobitic mysid shrimp Spelaeomysis quinterensis. Astyanax mtDNA and mysid histone H3 DNA sequences showed that in both species, cave populations in central El Abra, such as Tinaja cave, are broadly different from other cave populations. This phylogeographical convergence supports the notion that the central Sierra de El Abra is a biogeographical zone with effective barriers for either cave to cave or surface to cave gene flow, which have modulated the evolutionary history across species of its aquatic stygobitic community.
\end{abstract}

\section{Keywords}

Sierra de El Abra, cavefish, Spelaeomysis quinterensis, Astyanax mexicanus, convergent evolution, phylogeography 


\section{Introduction}

The teleost Astyanax mexicanus has become one of the most influential models for studying regressive evolution and cave adapted organisms. The species consists of several eyeless, depigmented cave-dwelling forms and eyed, pigmented surface-dwelling forms. Since the forms remain interfertile, this allows exploration of the molecular, genetic, and developmental mechanisms of adaptation to the cave environment (Jeffery 2012). The surfacedwelling forms inhabit a high variety of hydrological systems (i.e. lakes, rivers, lagoons, cenotes, etc.) throughout Mesoamerica region, while the stygobitic forms inhabit a series of subterranean systems in the Sierra de El Abra, Sierra de Guatemala, and Micos area, in Northeast Mexico. The Sierra de El Abra, where the largest abundance of caves with cavefish populations are located, (i.e. 21 populations currently discovered), is a long $(120 \mathrm{~km})$ and narrow $(10 \mathrm{~km})$ limestone ridge. Despite its success as a model organism for study in the field of evolutionary development, there is still considerable controversy regarding its phylogeography (e.g. Ornelas-García et al. 2008; Bradic et al. 2012, Strecker et al. 2012). Central to this discussion has been the question of how many times have the surface populations independently colonized the cave environment and how much underground dispersal has occurred to establish the current cave populations. A plethora of publications have accumulated over time with terms such as phylogenetically old/new populations, lineages $\mathrm{A} / \mathrm{B}$, phylogenetically old/new clusters, and old/new epigean stocks, with individual cavefish populations assigned contradictorily to one or to another set (Gross 2012).

Initial genetic studies with isoenzymes (Avise and Selander 1972) and RAPDs (Espinasa and Borowsky 2001) supported that all of the Sierra de El Abra cave populations were monophyletic, suggestive of high underground dispersal amongst caves. However, when mtDNA was first sequenced (Dowling et al. 2002), results showed a drastically different scenario. A phylogeographical discordance was evident, where the populations were not necessarily most closely related to their nearest geographical neighbors. The northernmost cave in Sierra de El Abra (Pachón cave) and the southernmost cave (Chica cave) shared an identical haplotype, while populations from caves in the center (Curva, Sabinos and Tinaja) shared a broadly different group of haplotypes. Aforementioned authors labeled them as lineage $\mathrm{A}$ and lineage $\mathrm{B}$ respectively. This lineage $\mathrm{B}$ of centrally located cave populations is very different from the northernmost and southernmost cave populations, being more closely related to Astyanax aeneus from Costa Rica than to lineage A (Dowling et al. 2002). Authors suggested that lineage $A$ and lineage $B$ colonized independently the cave environment. Later studies including a larger data set with mitochondrial loci (e.g. $16 \mathrm{~S}$ rDNA, Cox1, Cytb in Ornelas-García et al. 2008) recovered a similar pattern.

Recent studies evaluating mtDNA, nuclear and genomic data in cave and surface populations of Astyanax have shown a discordance between nuclear and mitochondrial phyletic patterns (e.g. Strecker et al. 2011; Coghill et al. 2014, Ornelas-García and Pedraza-Lara 2015). While mtDNA shows central caves such as Tinaja cave populations as very distant and of paraphyletic origin to northern and southern caves populations like Pachón and Chica, nuclear DNA can show the central cave populations as closely related to the other El Abra cave populations at the exclusion of surface populations. 


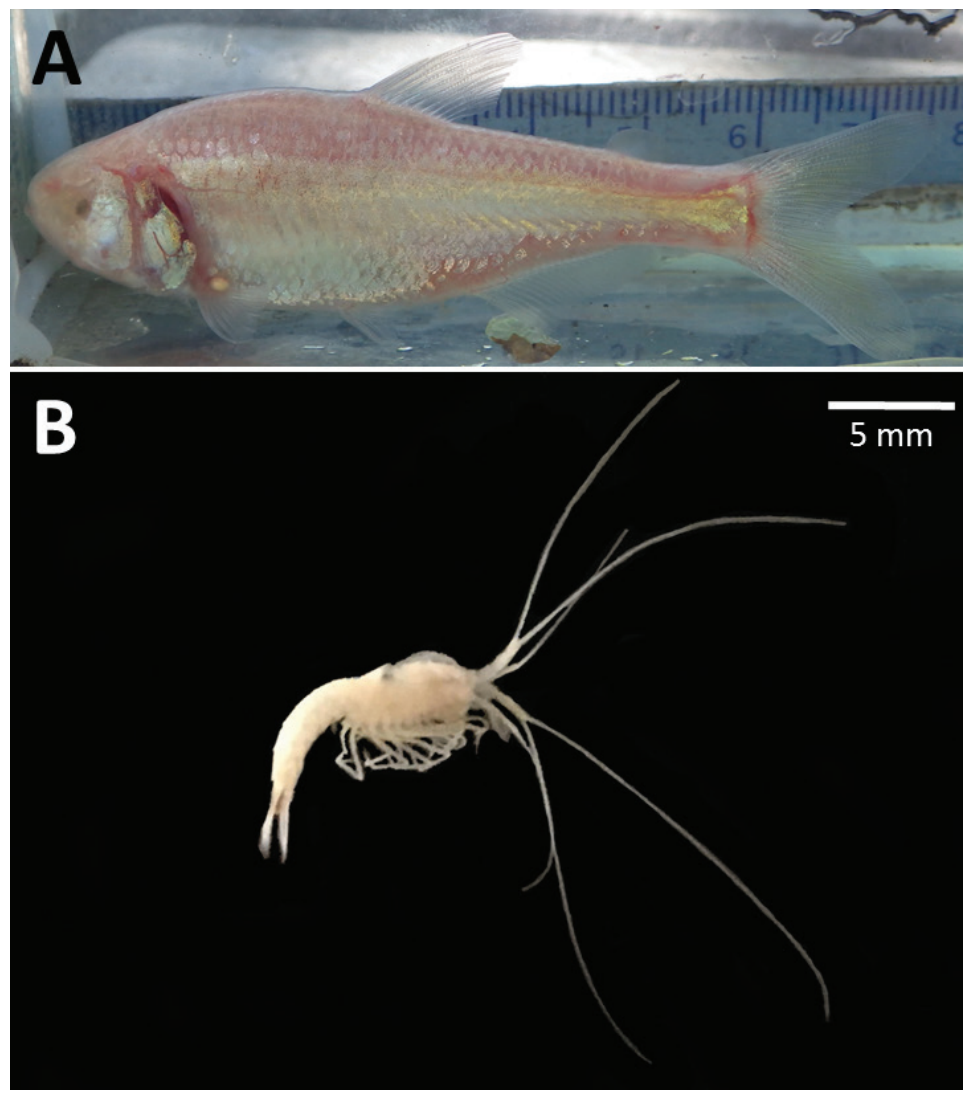

Figure I. A Astyanax mexicanus from Chiquitita cave B The mysid shrimp, Spelaeomysis quinterensis, also from Chiquitita cave. Both stygobitic organisms have overlapping biogeographic ranges throughout the El Abra karstic area, in northeaster Mexico.

A possible solution to this discordance comes from admixture analyses, which indicated that there has been recent gene flow between distinct mitochondrial clades with mitochondrial "capture" that occurred between some caves (e.g. Pachón and Chica) to neighboring surface populations (Gross 2012).

Yoshizawa et al. (2012) proposed that the disparity in nuclear and mtDNA in cavefish populations that have hybridized with surface fish can be explained by paternal inheritance of Vibration Attraction Behavior (VAB). The results suggest that parental genetic effects in adaptive behaviors may be an important factor in biasing mtDNA inheritance in natural populations that are subject to introgression. Another hypothesis examined here is that there may be barriers for cave-to-cave or surface-to-cave gene flow that created evolutionary significant units localized in discrete biogeographical areas of the Sierra de El Abra. These barriers may affect the phylogeographic patterns of all the aquatic communities inhabiting this network of underground rivers. We have thus studied the phylogeny of another aquatic organism whose size and biogeographical range overlaps with Astyanax, the mysid shrimp Spelaeomysis quinterensis (Fig. 1B). 


\section{Materials and methods}

Samples of Astyanax cavefish (Fig. 2) were collected from the following localities and they are ordered from north to south; Molino $(\mathrm{N}=2)$, Caballo Moro $(\mathrm{N}=2)$, Pachón $(\mathrm{N}=2)$, Sabinos $(\mathrm{N}=2)$, Tinaja $(\mathrm{N}=3)$, Curva $(\mathrm{N}=1)$, Chica $(\mathrm{N}=1)$, and Chiquitita $(\mathrm{N}=4)$. "Chiquitita" cave should not be confused with "Chica" cave. Chiquitita is the most recently discovered cave with a cavefish population (Espinasa et al. 2018), found south of Chica cave, in the town of El Pujal, at the southernmost tip of Sierra de El Abra.

Samples were also collected from a surface locality inhabited by Lineage A Astyanax; Río Comandante $(\mathrm{N}=2)$, and from two surface localities inhabited by Lineage B Astyanax; Rascón $(\mathrm{N}=2)$ and Tamasopo $(\mathrm{N}=1)$. Collecting permit \# SGPA/ DGVS/02438/16 from Secretaría del Medio Ambiente y Recursos Naturales, México, was issued to Patricia Ornelas García.

Samples of S. quinterensis were collected from four different cave localities (Fig. 2). From north to south, Caballo Moro $(\mathrm{N}=1)$ in the Sierra de Guatemala, and Pachón $(\mathrm{N}=2)$, Tinaja $(\mathrm{N}=3)$, and Chiquitita $(\mathrm{N}=1)$ from the Sierra de El Abra. Localities where $\mathrm{N}=1$ was due to the fact that no more specimens could be found in these difficult to access caves, as is often the case in cave studies. In localities where $\mathrm{N}>1, \mathrm{Bp}$ differences with populations was cero (See results), suggesting diversity within population was very low and thus supporting that mayor conclusions were not affected by sample size.

Genomic DNA was extracted using Qiagen's DNEasy ${ }^{\circ}$ Tissue Kit by digesting a fin clip or a leg in lysis buffer. For Astyanax samples, all markers were amplified and sequenced as a single fragment using the 16Sar (5' CGCCTGTTTATCAAAAACAT 3') and 16sb (5' CTCCGGTTTGAACTCAGATCA 3') primer pair for mitochondrial $16 \mathrm{~S}$ rRNA, following standard protocols (Espinasa et al. 2007). Since this particular primer pair is inefficient for amplifying crustaceans in general and since the goal of this study was only to get phylogeny of both groups without regard to having different molecular clocks among markers, S. quinterensis were amplified instead with the following primer pairs: H3aF (5' ATGGCTCGTACCAAGCAGACVGC 3') and H3aR (5' ATATCCTTRGGCATRATRGTGAC 3') for histone H3 (Espinasa et al. 2007). Amplification was carried out in a $50 \mu$ volume reaction, with Qiagen's Multiplex PCR kit. The PCR program for both markers consisted of an initial denaturing step at $94^{\circ} \mathrm{C}$ for $60 \mathrm{sec}$, followed by 35 amplification cycles $\left(94^{\circ} \mathrm{C}\right.$ for $15 \mathrm{sec}, 49^{\circ} \mathrm{C}$ for $15 \mathrm{sec}, 72{ }^{\circ} \mathrm{C}$ for $15 \mathrm{sec}$ ), and a final step at $72{ }^{\circ} \mathrm{C}$ for $6 \mathrm{~min}$ in a GeneAmp ${ }^{\circ} \mathrm{PCR}$ System 9700 (Perkin Elmer). PCR products were then subsequently cleaned with Qiagen's QIAquick PCR Purification Kit and sent to SeqWeight for direct sequencing. Chromatograms obtained from the automated sequencing were read and contigs made using the sequence editing software SequencherTM 3.0. External primers were excluded from the analyses. Sequence identity was confirmed through BLAST analyses. Sequences were aligned and phylogeny trees obtained with ClustalW2 and base pair differences were counted with SequencherTM 3.0. 


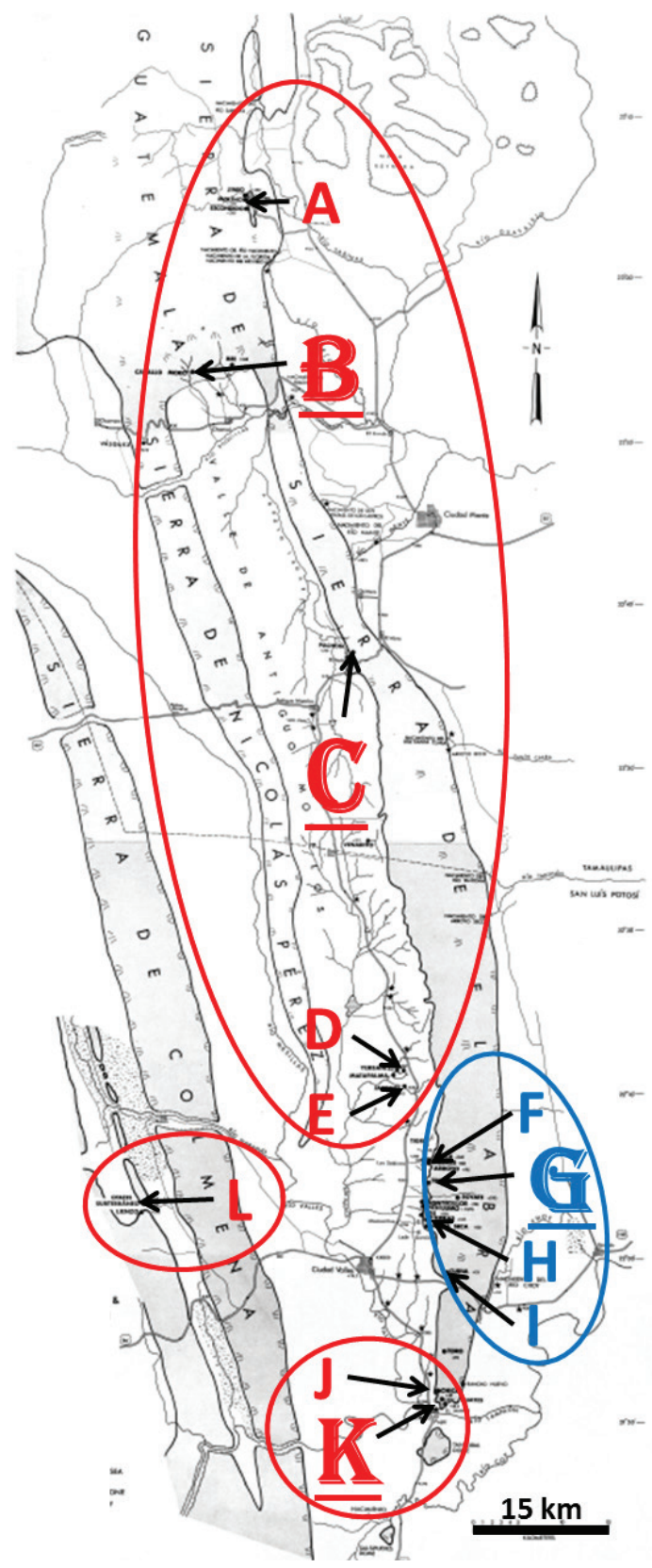

Figure 2. Cave localities of $A$. mexicanus whose mitochondrial DNA has been analyzed. With larger font and underlined are localities where $S$. quinterensis were also collected. In red are caves harboring lineage $\mathrm{A}$ and in blue those with lineage B for both mtDNA in Astyanax and histone 3 for $S$. quinterensis. Notice that lineage B is restricted to a small biogeographical zone, circled in blue. A Molino B Caballo Moro C Pachón D Yerbaniz E Japones $\mathbf{F}$ Sabinos $\mathbf{G}$ Tinaja H Piedras I Curva J Chica K Chiquitita L Rio Subterraneo. (Figure modified from Mitchell et al. 1977). 


\section{Results}

All fragments for the mitochondrial 16S rRNA of Astyanax were $572 \mathrm{bp}$ long. There were no indels when aligning the sequences. Specimens from Molino, Caballo Moro, Pachón, Chica, and Chiquitita caves and from the surface locality of Río Comandante all had identical sequences, except one out of four specimens from Chiquitita cave that differed by $1 \mathrm{bp}(0.17 \%)$. The consensus sequence was also identical to GenBank sequence (AP011982.1) of "Astyanax mexicanus mitochondrial DNA, almost complete genome". Since the localities of Molino, Pachón, Chica and Río Comandante are previously known to harbor lineage A mtDNA (Gross 2012), the newly assessed cave populations of Caballo Moro, and Chiquitita caves are determined to also have lineage A mtDNA.

The cave populations of Sabinos, Tinaja and Curva had identical sequences. Likewise the surface populations of Rascón and Tamasopo were identical. These five localities are known to harbor fish from the Lineage B (Gross 2012). Our surface sequences of lineage B differ from the Lineage A sequences by 2 bp (0.34\%) at the 572 bp fragment positions of 296(A/G) and 297(A/C) respectively. Additionally, our cave sequences of lineage $\mathrm{B}$ differ from the Lineage A sequences by $5 \mathrm{bp}(0.87 \%)$ at the 572 bp fragment positions of 198(G/A), 262(C/T), 296(A/G), 297(A/G), and 329(T/C) respectively.

Regarding the mysid shrimp, the $\mathrm{H} 3$ fragment from all seven specimens were 328 bp long (GenBank \# MH422492-MH422494). There was no need for insertions or deletions to align the sequences. In the localities where more than one specimens was sequenced (Pachón $\mathrm{N}=2$ and Tinaja $\mathrm{N}=3$ ), no variability within populations was found and their sequences were identical. Two clades or lineages were found. The first lineage included specimens from Caballo Moro, Pachón and Chiquitita. The second lineage was made of Tinaja (Fig. 3). Similarity of sequences among populations did not follow geographical proximity between caves (Figs 3-4). Specimens from the northernmost (Pachón) and the southernmost (Chiquitita) portions of Sierra de El Abra were identical. The northernmost specimen, from Sierra de Guatemala, differed from these two Sierra de El Abra populations by 7 bp (2.1\%). Specimens from central Sierra de El Abra (Tinaja) were the most distinct, differing by 31-36 bp (9.4-10.9\%) from all of the aforementioned localities. The Tinaja lineage is close to 5 times more different than Sierra de Guatemala populations are to Sierra de El Abra. It is unexpected to find that within the Sierra de El Abra, Tinaja cave is so drastically divergent to the other populations from the same region. In particular because this population is located geographically in between two populations that had identical sequences, Pachón and Chiquitita (Fig. 2).

\section{Discussion}

To our knowledge, a total of 12 out of the 30 caves known to harbor cavefish in the El Abra region have had their mtDNA sequenced thus far, with the inclusion of the new 


\begin{tabular}{|c|c|c|c|c|}
\hline \multicolumn{5}{|c|}{ Mysid Histone base pair difference } \\
\hline & $\begin{array}{c}\text { Caballo } \\
\text { Moro } \\
(\mathbf{N}=1)\end{array}$ & $\begin{array}{c}\text { Pachon } \\
(\mathbf{N = 2 )}\end{array}$ & $\begin{array}{c}\text { Tinaja } \\
(\mathbf{N}=3)\end{array}$ & $\begin{array}{c}\text { Chiquitita } \\
(\mathbf{N}=1)\end{array}$ \\
\hline $\begin{array}{c}\text { Sierra de } \\
\text { Guatemala } \\
\text { Caballo } \\
\text { Moro }\end{array}$ & 0 & - & - & - \\
\hline $\begin{array}{c}\text { North } \\
\text { El Abra } \\
\text { Pachon }\end{array}$ & 7 & 0 & - & - \\
\hline $\begin{array}{c}\text { Central } \\
\text { El Abra } \\
\text { Tinaja }\end{array}$ & 31 & 36 & 0 & - \\
\hline $\begin{array}{c}\text { South } \\
\text { El Abra } \\
\text { Chiquitita }\end{array}$ & 7 & 0 & 36 & 0 \\
\hline
\end{tabular}

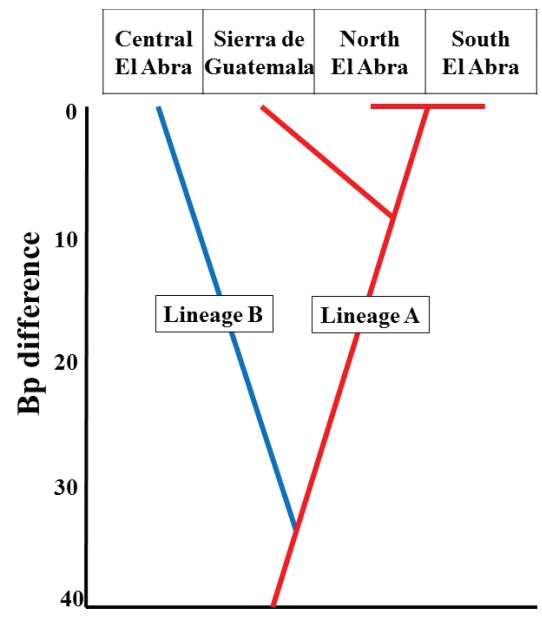

Figure 3. A, Base pair differences of histone 3 sequences between mysid shrimps. Specimens from central Sierra de El Abra (Lineage B) are markedly different from all other populations (Lineage A).

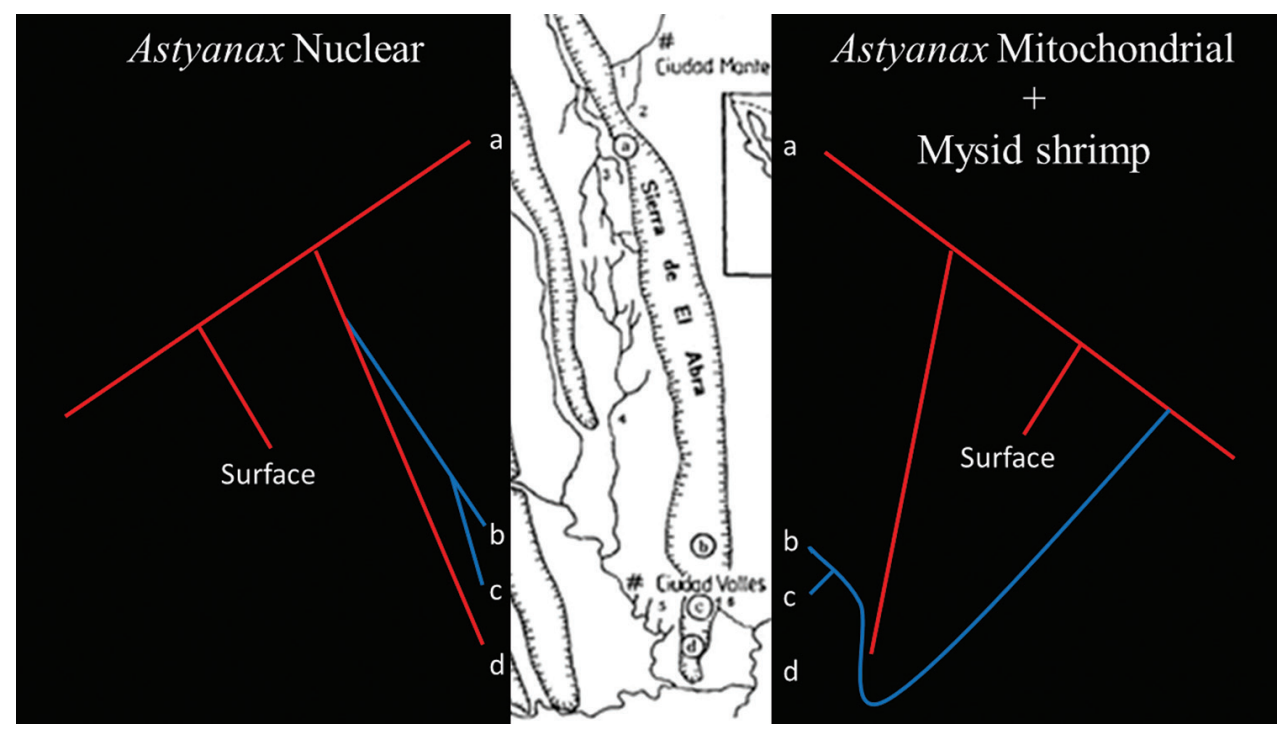

Figure 4. Pylogeographical convergence between mysid shrimps in the Sierra de El Abra and the mtDNA of Astyanax cavefish (right). Both aquatic species harbor the evolutionary signature of a phylogeographical discordance, where genetic markers of populations in central Sierra de El Abra are extremely distinct from the rest of the populations. Nuclear tree (left) based on the consensus of isoenzymes, RAPDs, microsatellite, and genomic sequences. a) Pachón as representative of northern populations. b-c) Sabinos and Tinaja as representative of central populations. d) Chica and Chiquitita as representative of southern populations.

Astyanax populations of this study. From this wealth of data, a pattern seems to emerge (Figs 2, 4). Cave populations with Lineage B mtDNA (Sabinos, Tinaja, Piedras and Curva) are restricted to an area in central Sierra de El Abra. This region is localized be- 
tween $15 \mathrm{~km}$ north of Ciudad Valles to directly east of the city. The northern (Pachón, Yerbaniz and Japonés) and southern (Chica and Chiquitita) portions of Sierra de El Abra, Sierra de Guatemala (Molino and Caballo Moro), and Micos (Río Subterraneo) areas are all inhabited by cavefish with Lineage A mtDNA.

Results obtained from the stygobitic shrimp suggest that mysids in central Sierra de El Abra (Tinaja) derive also from a separate lineage different from the rest of the Sierra de El Abra (Pachón and Chiquitita caves) and Sierra de Guatemala (Caballo Moro) populations. This implies that the aquatic mysid shrimps had at least two separate evolutionary histories, or lineages, which are linked to distinct geographical areas within the Sierra de El Abra. The phylogeography of the mysids lineages is in agreement and overlaps with the mitochondrial lineages of Astyanax cavefish (Fig. 4). This phylogeographical convergence supports that some caves in the central area of Sierra de El Abra, where Tinaja cave is located, are within a biogeographical zone that has modulated to a certain extent the evolutionary histories across multiple aquatic stygobitic species. Probably, this has kept them partially isolated from gene flow from other El Abra zones or from surface populations.

Since this pattern has now been shown to be similar in two distinct taxa of aquatic organisms, Astyanax and mysid shrimps, it is proposed that independent colonization and/or underground barriers have created a separate biogeographical zones that promotes independent evolutionary histories across aquatic communities. Alternatively, some caves in this central zone are less connected to surface systems and therefore less prompt to be colonized or introgressed by surface populations. If surface gene flow is more difficult in the central area (i.e. Tinaja), this isolation could lead to population differentiation as observed in both mitochondrial Astyanax and in mysid shrimps. A caveat of this hypothesis is that it would require mysid shrimps to currently have a surface morph or a surface ancestor that has or had access to only northern and southern caves in recent times. Spelaeomysis quinterensis is a highly troglomorphic species that is unlikely to survive on the surface, and unlike Astyanax, no surface morph has been described. This study opens the necessity to further investigate the sister group of this species to better understand the evolutionary history of this group and their adaptation to the caves environment. Furthermore, any proposed barriers should not be considered as completely impermeable and effective to eliminate all gene flow. This is evidenced in nuclear sequences in Astyanax which show a different pattern from mitochondrial data, corroborating that at least some gene flow either from within the caves or from surface to caves exist (Ornelas-García and Pedraza-Lara, 2015).

Barriers for dispersal for aquatic and terrestrial organisms in the El Abra caves appear to be different. Espinasa et al. (2014) sequenced the 16S rRNA of Anelpistina quinterensis (Nicoletiidae, Zygentoma, Insecta), a highly troglomorphic nicoletiid silverfish insect that inhabits from southern Sierra de El Abra to Sierra de Guatemala. Using a calibrated molecular clock, their data supports that this species migrated underground to reach both mountain ranges within less than 12,000 years, implying relatively easy underground migration, with no isolating evolutionary barrier for the 
central Sierra de El Abra, in terrestrial cave populations. So it would appear that at least for land troglobites, their phylogeography is different from aquatic species.

In conclusion, phylogeographic results obtained from the mysid Shrimp, Spelaeomysis quinterensis mimic the results of mitochondrial studies in Astyanax. This suggests that the geographic distribution of mitochondrial lineages in Astyanax is neither stochastic, nor exclusively explained by linkage to paternally inherited characters on distinct populations. Instead it supports that Sierra de El Abra has distinct biogeographic areas, with partial barriers that affect evolutionary histories creating evolutionary significant units for all members across different species of the aquatic cave community.

\section{Acknowledgments}

We would like to thank Sylvie Retaux, Emily Collins, Jenna Robinson, Jennifer Rutkowski, and Christian Schroeder who helped with specimen collection and or analysis. Patricia Ornelas-Garcia for reviewing the manuscript. Sequencing was performed with the help of students of the Spring 2017 BIOL320 Genetics course at Marist College. Partial support for the project was granted by the School of Science at Marist College and VPAA grants.

\section{References}

Avise JC, Selander RK (1972) Evolutionary genetics of cave-dwelling fishes of the genus Astyanax. Evolution 26: 1-19. https://doi.org/10.1111/j.1558-5646.1972.tb00170.x

Dowling TE, Martasian DP, Jeffery WR (2002) Evidence for multiple genetic forms with similar eyeless phenotypes in the blind cavefish, Astyanax mexicanus. Molecular Biology and Evolution 19: 446-455. https://doi.org/10.1093/oxfordjournals.molbev.a004100

Espinasa L, Bartolo ND, Newkirk CE (2014) DNA sequences of troglobitic nicoletiid insects support Sierra de El Abra and the Sierra de Guatemala as a single biogeographical area: Implications for Astyanax. Subterranean Biology 13: 35-44. https://doi.org/10.3897/subtbiol.13.7256

Espinasa L, Borowsky RB (2001) Origins and Relationship of Cave Populations of the Blind Mexican Tetra, Astyanax Fasciatus, in the Sierra De El Abra. Environmental Biology of Fishes 62(1-3): 233-237. https://dx.doi.org/10.1023/A:1011881921023

Espinasa L, Flick C, Giribet G (2007) Phylogeny of the American silverfish Cubacubaninae (Hexapoda: Zygentoma: Nicoletiidae): a combined approach using morphology and five molecular loci. Cladistics 23(1): 22-40. https://doi.org/10.1111/j.10960031.2006.00127.x

Espinasa L, Legendre L, Fumey F, Blin M, Rétaux S, Espinasa M (2018) A new cave locality for Astyanax cavefish in Sierra de El Abra, Mexico. Subterranean Biology 26: 39-53. https:// doi.org/10.3897/subtbiol.26.26643 
Hausdorf B, Wilkens H, Strecker U (2011) Population genetic patterns revealed by microsatellite data challenge the mitochondrial DNA based taxonomy of Astyanax in Mexico (Characidae, Teleostei). Molecular phylogenetics and evolution 60(1): 89-97. https://doi. org/10.1016/j.ympev.2011.03.009

Gross JB (2012) The complex origin of Astyanax cavefish. BMC Evolutionary Biology 12(105): 1-12. https://doi.org/10.1186/1471-2148-12-105

Jeffery WR (2012) Astyanax mexicanus: A model organism for evolution and adaptation. In: White WB, Culver DC (Eds) Encyclopedia of Caves (Second Edition). Academic Press, New York, 36-43. https://doi.org/10.1016/B978-0-12-383832-2.00006-2

Mitchell RW, Russell WH, Elliot WR (1977) Mexican eyeless characin fishes, genus Astyanax: environment, distribution, and evolution. Special Publications of the Museum of Texas Tech University 12: 1-89.

Ornelas-Garcia CP, Dominguez-Dominguez O, Doadrio I (2008) Evolutionary history of the fish genus Astyanax Baird \& Girard (1854) (Actinopterygii, Characidae) in Mesoamerica reveals multiple morphological homoplasies, BMC Evolutionary Biology 8: 340. http:// doi.org/10.1186/1471-2148-8-340

Ornelas-García CP, Pedraza-Lara C (2015) Phylogeny and Evolutionary History of Astyanax mexicanus. Biology and Evolution of the Mexican Cavefish, 77.

Strecker U, Faúndez VH, Wilkens H (2004) Phylogeography of surface and cave Astyanax (Teleostei) from Central and North America based on cytochrome b sequence data. Molecular Phylogenetics and Evolution 33(2): 469-481. https://doi.org/10.1016/j. ympev.2004.07.001

Strecker U, Hausdorf B, Wilkens H (2012) Parallel speciation in Astyanax cave fish (Teleostei) in Northern Mexico. Molecular phylogenetics and evolution, 62(1): 62-70. https://doi. org/10.1016/j.ympev.2011.09.005

Yoshizawa M, Ashida G, Jeffery WR (2012) Parental genetic effects in a cavefish adaptive behavior explain disparity between nuclear and mitochondrial DNA. Evolution; International Journal of Organic Evolution 66(9): 2975-2982. http://doi.org/10.1111/j.15585646.2012.01651.x 